\title{
Redefining Modernization in Russia ${ }^{*}$
}

Rev. of: Kivinen, M., Humphreys, B. (Eds.). (2020). Russian Modernization: A New Paradigm / foreword by T. Halonen. Abingdon, Routledge. 394 p.

\section{Daria Dergacheva}

Autonomous University of Barcelona, Barcelona, Spain

The authors of the collection of interdisciplinary articles united by the new paradigm of Russian modernization try to explain and raise new questions on contemporary Russia from its economy to the political regime, from changes in social welfare to cultural shifts. While the book provides rigorous and interesting research regarding modern Russian society, the reviewer considers it too broad at times, sometimes suggesting outdated case studies. More particularly, instead of focusing on the religious movement of rodnoverie or the process underlying the transformation of the CPSU into the modern CPRF, the authors could have referred to more modern cases. However, according to the reviewer, the collection is one of the most fascinating and profound studies on Russia that has been carried out lately.

Keywords: Russian modernization, political regime in Russia, Russian economy, Russian society, Russian politics

Авторы рецензируемого сборника междисциплинарных статей, объединенных новой парадигмой российской модернизации, ставят целью объяснить и задать новые вопросы о процессах в современной России в ее экономике и политике, социальной политике и культурных сдвигах. В книге представлены глубокие и интересные исследования, касающиеся современного российского социума, однако, по мнению рецензента, некоторые выбранные кейсы кажутся устарелыми. В частности, рассмотрение религиозного движения «Родноверие» или процесса перехода КПСС в современную КПРФ могло бы быть заменено на более современные кейсы. Несмотря на это, сборник, по мнению автора статьи, представляет одно из наиболее интересных и глубоких исследований современного российского общества.

Ключевые слова: российская модернизация, политический режим в России, российская экономика, российское общество, российская политика

* Citation: Dergacheva, D. (2021). Redefining Modernization in Russia. In Quaestio Rossica. Vol. 9, № 4. P. 1527-1532. DOI 10.15826/qr.2021.4.654.

Цитирование: Dergacheva D. Redefining Modernization in Russia // Quaestio Rossica. Vol. 9. 2021. № 4. P. 1527-1532. DOI 10.15826/qr.2021.4.654.

(C) Dergacheva D., 2021

Quaestio Rossica • Vol. 9 • 2021 • № 4, p. 1527-1532 
The collective work under review features articles by young and prominent researchers in the field of Russian studies. Among others, the tome showcases works by Vladimir Gel'man, who has just authored a book on Russian authoritarianism [Gelman]; Markku Kivinen, the director of the Aleksanteri Institute in Helsinki; Professor Emeritus Arto Mustajoki, an expert in Russian language and semantics at the University of Helsinki; and Kaarina Aitamurto, a specialist on the Russian religious sphere. It is also great to see, among many others, the input of researchers from newly emerging fields. Take, for instance, Daria Gritsenko, a specialist in the relatively new field of big data studies on Russia, or Saara Ratilainen, who studies social media in Russia and neighbouring countries.

This is one of the rare cases when the authors have applied a shared theoretical approach to modernity and modernization to a mixture of disciplines dedicated to Russian studies. Here, the editors cite Antony Giddens' structuration theory as a common starting point. As they indicate, this offers a broader opportunity for further research on a Russian "society undergoing enormous systematic changes since the collapse of the Soviet Union" [Russian Modernization, p. 10]. As the editors, Kivinen and Humphreys, state in the introduction, "most theoretical perspectives have so far neglected the complexity of Russian society, and for that reason, the theoretical approaches have not been able to open new horizons for studying ongoing, empirically observable processes" [Ibid.].

While interest in Russian studies is growing elsewhere in the world, Finnish academia is one of the few places that has never ceased financing and promoting the field. "In post-Cold war world, our field has an exceptional societal relevance", the editors state ${ }^{1}$ [Ibid., p. 11]. It is not a coincidence that the foreword to this volume is written by Tarja Halonen, a former president of Finland (2000-2012), who specifically highlights the importance of research on the broad area of Russian studies for her country. She says: "The post-Cold War environment requires a new analysis of Russia. When many other countries were downsizing their institutions of Russian studies, we have invested increasingly in this field from the mid-1990s. Since then, more and more Finnish scholars have examined Russian history, politics, and culture. We have also aimed at informed decision-making, creating networks of stakeholders in addition to academic expertise. The knowledge generated has been eagerly consumed; by Finnish politicians, by business, and by opinion makers" (p. 8).

Finland, which was once part of the Russian Empire (1809-1917) and which had armed conflicts with the USSR during WWII, has never ceased to be aware of the Russian presence. Today, says Halonen, "Although Russia has to make its own solutions, we have to acknowledge that global problems will touch Russia too and those cannot be solved without Russia. Vast ecological challenges such as climate change, and new security threats such as terrorism, global inequality, and poverty cannot be solved on the

${ }^{1}$ Further, the citations of the reviewed book are in round brackets with page numbers. 
basis of competitive national interests." "The world simply cannot afford a new Cold War", she adds (Ibid.), giving the book the slight impression of a political statement.

The volume's five sections are edited by recognized researchers in their fields. Discussions on the fossil fuel economy, attempts to diversify it, and political economy are provided by Pami Aaito of the University of Tampere and Anna Lowry of the Aleksanteri Institute. Vladimir Gel'man et al have written a chapter on authoritarian modernization and post-Soviet choices. The chapter on social policy is edited by Markku Kivinen, while one on culture is offered by both Marku Kivinen and Arto Mustajoki. Tuomas Forsberg, an expert on EU-Russia relations, and others have contributed to a piece on international relations and security policies.

The purpose of the book, however, is not only to suggest a new paradigm, but also to present existing research from the Center of Excellence in Russian Studies: "As a concluding volume, we have endeavored to produce a publication that will function less as a final 'report' or summary of findings than a) an attempt at a synthesis of the major thrust of our research and, b) a selective mosaic of the scholarship that the project produces" (p. 10).

While in some ways it is an advantage, the book's main problem is precisely that it is a mosaic. Some pieces fit together much better than others, and perhaps a different volume should have been published for those that do not. A few of examples of excellent research which fall out of the shared interdisciplinary and theoretical framework are the articles on the Communist Party (CPRF) and the rodnoverie religious movement.

The analysis of rodnoverie, a contemporary Slavic pagan religious movement, while illustrating a Russian shift "from the liberalism of the early 1990s towards stricter control" (p. 94) in religious policies, seems a bit out of date. While it is understandable that the research and field work was done on this group specifically, the theoretical framework might have benefited from a broader perspective on religious movements and their position in contemporary Russia. Given that out of 362 so-called political prisoners in Russia, 297 were jailed for religious beliefs (most of them from Muslim organizations forbidden in Russia and the others from Jehovah's Witnesses $^{2}$ (78 persons)) [Number of Political Prisoners in Russia], the volume would have probably benefited from analyzing such movements rather than rodnoverie.

Another example of research that is neither empirically nor, at times, methodologically up to date is the study of the Communist Party as it changed from the CPSU to its current shape, the CPRF, under the leadership of Gennady Ziuganov (p. 174-179). The author describes the CPRF as a party where the remnants of Leninist rhetoric, on the one hand, and Russian patriotism, on the other, co-exist, with the latter dominating: "It is absolutely not communist in the same sense as the old Communist Party of the Soviet Union (CPSU), since the Leninist jargon that pops up in

${ }^{2}$ Organization prohibited in Russia. 
its official documents and declarations, is more a reminiscence of the past than a serious directive for action. If one would define the real ideology of the party by a single term, it would be its geopolitics, in a conservative and "patriotic" sense of the word" (Ibid., p. 174). This is very interesting research indeed, but it remains unclear why one of the co-actors in the regime of electoral authoritarianism [Гельман], a useful secondhand player, is being described in such detail. Perhaps this would be justifiable if the piece was not directed at experts, but rather at the general public.

It is also not very clear why the case for the 'conservative turn' in postSoviet Russian culture is presented with a study on a very specific field, Soviet musicology (p. 171-174): once again, this is a piece of the mosaic that does not quite fit with the others. This is despite the fact that the author argues that "integrated multidisciplinary cooperation of the social and political sciences and humanities is required in the field of contemporary modernization analyses in national contexts. Excluding the perspective of cultural and intellectual history, we tend to dismiss the logic, reason, and motivation of deep-level cultural attitudes that participate in, or oppose, these changes" (Ibid., p. 175). It might make sense to offer insights on the cultural and intellectual history of Soviet Russia in a separate volume.

However, most of the case studies and inset examples are fascinating and up to date. For example, Kangasporo and Lassila (Ibid., p. 179-187) have a somewhat unique view on Russian populism. Given the heated discussions [Комментарий] about how the recent Nobel Peace Prize was given to Dmitry Muratov, the editor of Novaya Gazeta [Nobel Peace Prize], but not Alexey Navalny (the opposition politician currently in jail), this chapter may provide some insights.

Another great example of a unique case study is the research on migrant workers from the ex-Soviet Central Asian states [Aitamurto, p. 81], which openly talks about racist, stereotypical language and the construction of "otherness" in the Russian media, as well as racist street violence. Meanwhile, Susanna Hast [Ibid., p. 186] provides a detailed recounting of the Chechen war and its role in the future of Russia. Interestingly, in his latest essay on Russian "heterarchy", or politics between chaos and control, Richard Sakwa of the University of Kent describes the case of Chechnya as proof of the chaotic features of contemporary Russian governance: "While the Russian state enjoys the overwhelming preponderance of coercive power, it does not have the classic Weberian monopoly of force. For example, two wars have been fought since 1991 to deny Chechnya's independence, yet in a rhizomatic manner the republic remains an extra-constitutional enclave, enjoying the power to strike within Russia proper and even to conduct elements of a separate foreign policy" [Sakwa, p. 227].

Another revealing and interesting study is that of the successful reform of the adoption process and foster care, led by the Russian NGOs after Dima Yakovlev's case (2008) and implemented by the Russian government (p. 108). This case is part of a larger chapter on social policy in contemporary Russia (p. 92-140). It is rare to see positive evaluations of the reforms in Russia, 
since most of the research, maybe quite rightfully, focuses on the failures. The efforts of the civic sector in Russia are often overlooked, but in this book one can find a case of successful government and NGO cooperation.

From the point of view of communication researchers, the book lacks a detailed view on the Russian media, with no separate section devoted to it. The explanation may be that not one, but two volumes recently addressed this issue in Finland. The first, Freedom of Expression in Russia's New Mediasphere (edited by Mariëlle Wijermars and Katja Lehtisaari), was published in 2021 by Routledge, while the other - The Palgrave Handbook of Digital Russia Studies (edited by Daria Gritsenko, Mariëlle Wijermars and Mikhail Kopotev) - was published via open access in 2021 and is available on the Palgrave webpage [Freedom of Expression in Russia's New Mediasphere; The Palgrave Handbook of Digital Russia Studies].

To conclude, Russian Modernization: A New Paradigm is a profound collection of theoretically connected, interdisciplinary works within Russian studies, conducted with rigor and knowledge by the researchers of the Aleksanteri Institute in Helsinki. It may be praised for being much less biased than many other studies in the field, presenting not only the failings but also the (micro) achievements of post-Soviet Russia, while also explaining in detail the fortunate and unfortunate choices this society has made and still is making. The volume can be recommended to all researchers interested in Russian studies, be it economics, political science, culture, or international relations. One can only hope that more research collections from the Center of Excellence in Russian Studies will become publicly available. The book is currently accessible on the Routledge website.

\section{Список литературы}

Гельман В. Авторитарная Россия : Бегство от свободы, или Почему у нас не приживается демократия. М. : Альпина, 2021. 366 с.

Комментарий : Муратов, Навальный и драма вокруг Нобелевской премии мира // Deutche Welle : [сайт]. 2021. 8 окт. URL: https://www.dw.com/ru/kommentarij-muratovnavalnyj-i-drama-vokrug-nobelevskoj-premii-mira/a-59454484 (дата обращения: 09.10.2021).

Aitamurto K. Paganism, Traditionalism, Nationalism: Narratives of Russian Rodnoverie. L. ; N. Y. : Routledge, 2016. 232 p.

Freedom of Expression in Russia's New Mediasphere / ed. by K. Lehtisaari, M. Wijermars. L. ; N. Y. : Routledge, 2021. 72 p.

Nobel Peace Prize: Journalists Maria Ressa and Dmitry Muratov Share Award // BBC : [website]. 2021. Oct. 8. URL: https://www.bbc.com/news/world-58841973 (accessed: 09.10.2021).

Number of Political Prisoners in Russia from 2015 to 2020, by Type // Statista : [website]. 2020. Aug. 19. URL: https://www.statista.com/statistics/1142848/number-ofpolitical-prisoners-in-russia-by-type/ (accessed: 09.10.2021).

Russian Modernization: A New Paradigm / ed. by M. Kivinen, B. Humphreys ; foreword by T. Halonen. Abingdon : Routledge, 2020. 394 p.

The Palgrave Handbook of Digital Russia Studies / ed. by D. Gritsenko, M. Wijermars, M. Kopotev. Cham : Palgrave Macmillan, 2021. 612 p.

Sakwa R. Heterarchy: Russian Politics between Chaos and Control // Post-Soviet Affairs. Vol. 37. 2021. № 3. P. 222-241. DOI 10.1080/1060586X.2020.1871269. 


\section{References}

Aitamurto, K. (2016). Paganism, Traditionalism, Nationalism: Narratives of Russian Rodnoverie. L., N. Y., Routledge. 232 p.

Gelman, V. (2021). Avtoritarnaya Rossiya. Begstvo ot svobody, ili Pochemu u nas ne prizhivaetsya demokratiya [Authoritarian Russia. The Escape from Freedom, or Why Democracy Doesn't Take Root]. Moscow, Alpina. 366 p.

Gritsenko, D., Wijermars, M., Kopotev, M. (Eds.). (2021). The Palgrave Handbook of Digital Russia Studies. Cham, Palgrave Macmillan. 612 p.

Kivinen, M., Humphreys, B. (Eds.). (2020). Russian Modernization: A New Paradigm / foreword by T. Halonen. Abingdon, Routledge. 394 p.

Kommentarii. Muratov, Naval'nyi i drama vokrug Nobelevskoi premii mira [Commentary: Muratov, Navalny, and the Drama around the Nobel Peace Prize]. (2021). In Deutche Welle [website]. 2021. Oct. 8. URL: https://www.dw.com/ru/kommentarij-muratov-navalnyj-idrama-vokrug-nobelevskoj-premii-mira/a-59454484 (accessed: 09.10.2021).

Lehtisaari, K., Wijermars, M. (Eds). (2021). Freedom of Expression in Russia's New Mediasphere. L., N. Y., Routledge. 72 p.

Nobel Peace Prize: Journalists Maria Ressa and Dmitry Muratov Share Award. (2021). In $B B C$ [website]. Oct. 8. URL: https://www.bbc.com/news/world-58841973 (accessed: 09.10.2021).

Number of Political Prisoners in Russia from 2015 to 2020, by Type. (2020). In Statista [website]. Aug. 19. URL: https://www.statista.com/statistics/1142848/number-of-politicalprisoners-in-russia-by-type/ (accessed: 09.10.2021).

Sakwa, R. (2021). Heterarchy: Russian Politics between Chaos and Control. In PostSoviet Affairs. Vol. 37. No. 3, pp. 222-241. DOI 10.1080/1060586X.2020.1871269.

The article was submitted on 10.10.2021 